\title{
Method comparison between Munich II and III nomenclature for Pap smear samples
}

\author{
Christoph Cirkel, Claudia Barop, Daniel A. Beyer \\ Department of Obstetrics and Gynecology, University Hospital Schleswig-Holstein/Campus Luebeck, Luebeck, Germany
}

\begin{abstract}
Objective: Munich Nomenclature III for cervical smear evaluation also known as Papanicolaou (Pap) smear was launched in Germany in July 2014, and it is the only used system in Germany. The study aims at a method comparison between the previously used nomenclature Munich II and the currently used Munich III.

Material and Methods: A method comparison was performed by analyzing 117 Pap smear samples (pss) in the cytological laboratory of the department of Obstetrics and Gynecology of Luebeck University between January and March 2014. The samples were evaluated twice using both nomenclatures (Munich II and Munich III).

Results: One out of the 117 pss showed a loss of cellular material. According to Munich III, this Pap smear should be linked to group 0. Concerning Pap I, Munich II showed 0/117 pss (0\%) and Munich III showed 55/117 pss (47\%) cases ( $<<0.001)$. Pap II results were seen less frequently in Munich III than in Munich II (47\% vs 93\%, p<0.001). Pap IVa, IVb, and V stay similar in both nomenclatures [IVa: $1 / 117$ pss ( $0.85 \%)$, IVb: 0/117 pss (0\%) and V: $1 / 117$ pss (0.85\%)].

Conclusion: Patients at risk are clearly separated by Munich III from those with no evidence of pathology. The former clusters have been extended by distinctly defined subgroups, resulting in a more precise way to differentiate cytological findings. Differentiating between Pap IIID 1 and IIID 2 clearly separates mild and moderate dysplasia [cervical intraepithelial neoplasia (CIN) 1 (CIN 1) and CIN 2)].

(J Turk Ger Gynecol Assoc 2015; 16: 203-7)
\end{abstract}

Keywords: Munich nomenclature II, Munich nomenclature III, Pap smear

Received: 30 July, 2015

Accepted: 14 October, 2015

\section{Introduction}

Papanicolaou (Pap) smear samples have been shown to detect cervical cancer even without a minor surgical procedure. This was first demonstrated by Traut et al. (1) 1943. Cytological findings were originally classified into 5 groups by Papanicolaou et al. (2) in 1963 (Table 1).

Different classification systems for Pap smear samples have been internationally used (3). Germany applies the Munich nomenclature for Pap smear evaluation. The Munich nomenclature was established in 1975 as a modification of Papanicolaou's classification. This modification was necessary to meet the international requirements of a descriptive classification (4). In 1990, the Munich nomenclature was updated by the creation of Munich II. The revision of Munich II in 2013 led to the Munich III nomenclature in July 2014. Since January 12015 , Munich III has been established as the only system officially used in Germany.

With Munich III, new subgroups were created to categorize different grads of dysplasia. Unclear findings that are neither clearly reactive nor meet certain criteria of dysplasia are now marked. Munich III further differentiates between squamous, epithelial, and glandular cells (5).
Furthermore, the Munich III system is attempting to make cytological findings transferrable to the internationally more commonly used The Bethesda System. This offers the opportunity to compare them with international studies (Table 2).

The aim of the study was a method comparison between Munich II and the newly defined nomenclature Munich III.

\section{Material and Methods}

Method comparison was done by analyzing 117 Pap smear samples in the cytological laboratory at the department of Obstetrics and Gynecology of Luebeck University between January and March 2014. All Pap smear samples were

Table 1. Papanicolaou's classification of cervical smear samples (2)

\begin{tabular}{|l|l|}
\hline Class I & Absence of atypical or abnormal cells \\
\hline Class II & Atypical cytology, but no evidence of malignancy \\
\hline Class III & $\begin{array}{l}\text { Cytology suggestive of but not conclusive of } \\
\text { malignancy }\end{array}$ \\
\hline Class IV & Cytology strongly suggestive of malignancy \\
\hline Class V & Cytology conclusive for malignancy \\
\hline
\end{tabular}


Table 2. Comparison of classifications Munich II, Munich III, and The Bethesda System (modified after Griesser et al. (5), 2013)

\begin{tabular}{|c|c|c|c|c|}
\hline \multicolumn{2}{|c|}{ Munich II Nomenclature } & \multicolumn{2}{|c|}{ Munich III Nomenclature } & \multirow{2}{*}{$\begin{array}{l}\text { The Bethesda System } \\
\text { Unsatisfactory for evaluation }\end{array}$} \\
\hline \multirow{3}{*}{ I } & \multirow{3}{*}{ Normal cell pattern } & 0 & $\begin{array}{l}\text { Unsatisfactory specimen } \\
\rightarrow \text { repeat Pap smear }\end{array}$ & \\
\hline & & I & $\begin{array}{l}\text { Normal or unsuspicious cell pattern } \\
\rightarrow \text { Pap smear next routine checkup }\end{array}$ & NILM \\
\hline & & Ila & $\begin{array}{l}\text { Normal cell pattern with suspicious } \\
\text { patient history } \\
\rightarrow \text { consider control Pap smear due to } \\
\text { suspicious patient history (cytologic/ } \\
\text { histologic/colposcopic/clinical findings) }\end{array}$ & NILM \\
\hline & \multirow{4}{*}{$\begin{array}{l}\text { Mild inflammatory, regenerative, } \\
\text { metaplastic, or degenerative changes }\end{array}$} & II & Findings with low protective value & \\
\hline & & II-p & $\begin{array}{l}\text { Squamous epithelium with low-grade } \\
\text { changes of the nucleus; less than CIN } 1 \text {, } \\
\text { also with coilocystic cytoplasm/paraceratotic } \\
\text { changes } \\
\rightarrow \text { if applicable, control Pap smear } \\
\text { considering patient history and clinical } \\
\text { findings (possibly after inflammation } \\
\text { treatment and/or hormonal treatment; in } \\
\text { special cases additional diagnostic methods } \\
\text { and/or colposcopy) }\end{array}$ & ASC-US \\
\hline & & II-g & $\begin{array}{l}\text { Abnormal cervical glandular cells; more } \\
\text { than reactive changes } \\
\rightarrow \text { consider control Pap smear depending } \\
\text { on patient history and clinical findings } \\
\text { (possibly after inflammation treatment, in } \\
\text { special cases additional methods and/or } \\
\text { colposcopy) }\end{array}$ & AGC endocervical NOS \\
\hline & & II-e & $\begin{array}{l}\text { Endometrial cells; women }>40 \text { y.o. and } \\
\text { second half of the cycle } \\
\rightarrow \text { clinical checkup considering patient } \\
\text { history and clinical findings }\end{array}$ & Endometrial cells \\
\hline & \multirow{5}{*}{$\begin{array}{l}\text { Unclear findings: severely inflammatory } \\
\text { or degenerative and/or poorly preserved } \\
\text { cell material; abnormal glandular or } \\
\text { stromal cells; dysplasia, carcinoma } \\
\text { in situ, or invasive carcinoma not } \\
\text { excluded }\end{array}$} & III & Unclear findings & \\
\hline & & III-p & $\begin{array}{l}\text { CIN 2/CIN 3/squamous cell carcinoma } \\
\text { cannot be excluded } \\
\rightarrow \text { colposcopy, if applicable additional } \\
\text { diagnostic methods, possibly short-term } \\
\text { re-pap smear after inflammatory treatment } \\
\text { and/or hormonal treatment }\end{array}$ & ASC-H \\
\hline & & III-g & $\begin{array}{l}\text { Distinctive atypia of glandular cells, } \\
\text { adenocarcinoma in situ/invasive } \\
\text { adenocarcinoma cannot be excluded } \\
\rightarrow \text { colposcopy, if applicable additional } \\
\text { diagnostic methods }\end{array}$ & $\begin{array}{l}\text { AGC endocervical favor } \\
\text { neoplastic }\end{array}$ \\
\hline & & III-e & $\begin{array}{l}\text { Abnormal endometrial cells } \\
\rightarrow \text { further clinical diagnostics, if applicable } \\
\text { with histological support }\end{array}$ & AGC entometrial \\
\hline & & III-X & $\begin{array}{l}\text { Unclear glandular cells of unknown origin } \\
\rightarrow \text { further diagnostics (e.g. diagnostic } \\
\text { curettage; if applicable additional } \\
\text { diagnostic methods/colposcopy) }\end{array}$ & AGC favor neoplastic \\
\hline \multirow{2}{*}{\multicolumn{2}{|c|}{ IIID Cells of mild or moderate dysplasia }} & IIID & $\begin{array}{l}\text { Dysplastic findings with greater tendency } \\
\text { of regression }\end{array}$ & \\
\hline & & IIID 1 & $\begin{array}{l}\text { Cells of mild dysplasia (CIN } 1 \text { ) } \\
\rightarrow \text { control Pap smear in } 6 \text { months, if } \\
\text { persisting for }>12 \text { months; colposcopy, } \\
\text { if applicable additional diagnostic methods }\end{array}$ & LSIL \\
\hline
\end{tabular}


Table 2. Continue

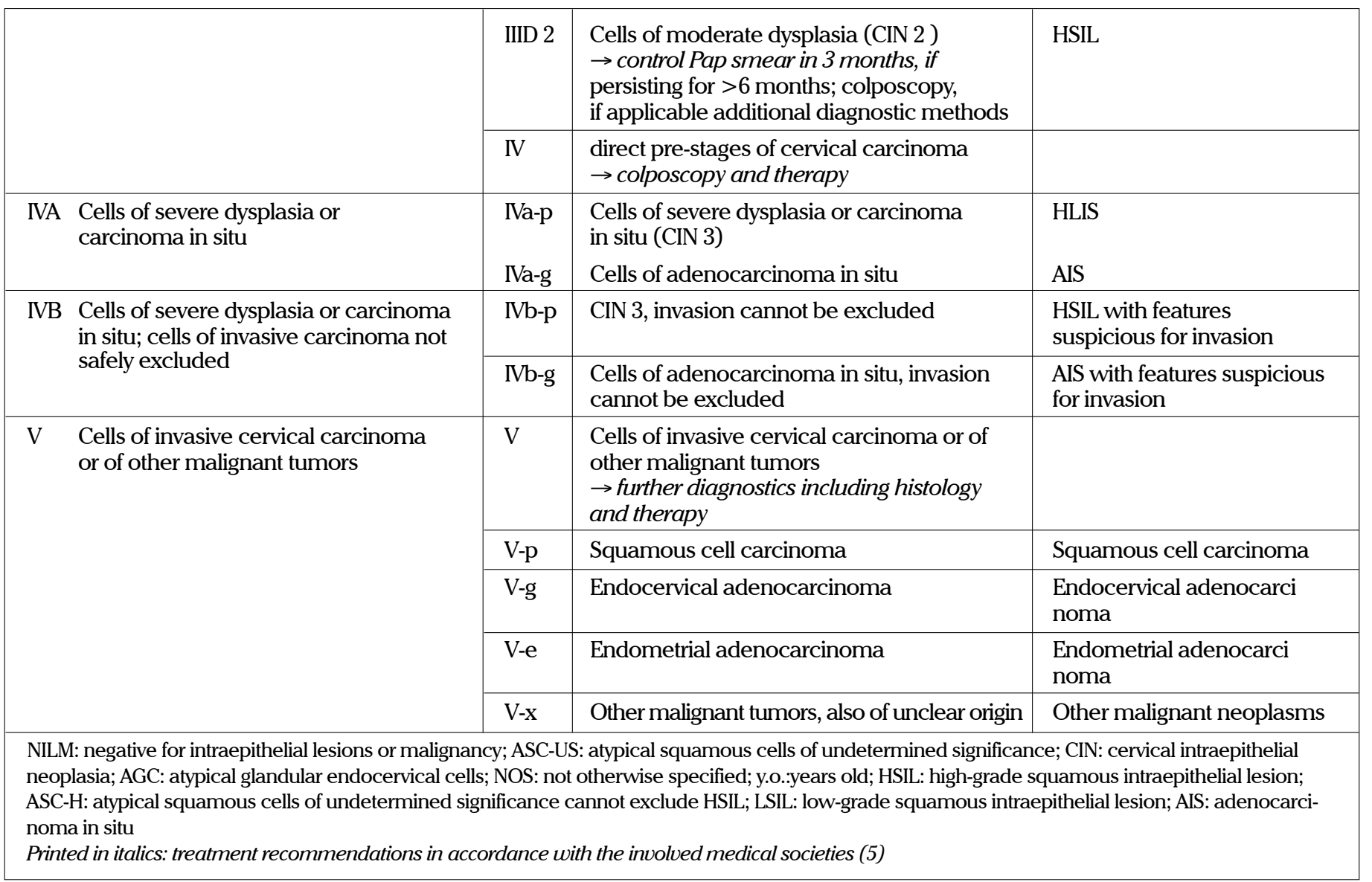

analyzed at our cytological laboratory during this time period. No exclusion criteria were in use. All patient samples were evaluated twice by certified cytologists using the Munich II and Munich III nomenclatures. Informed patient consent and ethical approval (\#12-234 Luebeck University) was obtained. Statistical analysis was performed with SPSS Statistics Version 22 (IBM Corporation; Armonk, USA).

\section{Results}

The classification of Pap I significantly differs in Munich II and III $(p<0.001)$. Results are presented in table 3 . While 0 of the 117 analyzed samples were classified as Pap I ("normal cell pattern") in Munich II, 55 were categorized as Pap I ("normal or unsuspicious cell pattern") in Munich III.

New subcategories in categories II and III of Munich III allow a more specific classification of Pap smear samples. Pap II findings were less frequently seen in Munich III (47\% vs 94\%, $\mathrm{p}<0.001$ ). Pap smear samples categorized in group III as "unclear findings" of the Munich nomenclatures stayed almost the same in both systems. One Pap smear sample showed the loss of cellular material. In Munich III, this Pap smear sample is now linked to the category 0 "unsatisfactory for evaluation." In Munich II, it has been classified in category III as an "unclear finding."
IIID Pap smear samples are subcategorized in Munich III in mild dysplasia (IIID 1) and moderate dysplasia (IIID 2).

The Pap smear samples classified as Pap IVa and Pap V in Munich II were classified as Pap IVa-p and Pap V-p due to the squamous cell origin.

\section{Discussion}

Many different cytology classification systems exist worldwide. European guidelines highly recommend that different systems should be transferrable into the internationally accepted and used The Bethesda System $(3,6)$. The German system, the Munich nomenclature, was created on the basis of the numerical Papanicolaou classification system for Pap smear samples (2). Pap smear evaluation and categorization are important for cervical cancer checkup. The incidences of cervical cancer have been reduced due to Pap smear examinations (5). Nonparticipation in cervical cancer screening is the most significant cause for persistent cervical cancer (7).

A detailed and exact classification system is essential to take necessary actions needed for treating cytological findings.

The new group 0 in Munich III clearly marks Pap smear samples unsatisfactory for evaluation and clears the former group III in Munich II. Pap smear findings with a benign background and findings that do not imply an increased risk of neoplasia 
Table 3. Comparison of Pap smear samples classified in Munich II and Munich III

\begin{tabular}{|c|c|c|c|c|}
\hline Munich II & Pss & Munich III & Pss & $\begin{array}{l}\text { Significant difference } \\
\text { between groups }\end{array}$ \\
\hline I & 0 & I & 55 & $\mathrm{p}<0.001$ \\
\hline \multirow[t]{4}{*}{ II } & \multirow[t]{4}{*}{110} & II-a & 32 & \multirow[t]{4}{*}{$\mathrm{p}<0.001$} \\
\hline & & II-p & 21 & \\
\hline & & II-g & 2 & \\
\hline & & II-e & 0 & \\
\hline \multirow[t]{3}{*}{ III } & \multirow[t]{3}{*}{4} & III-p & 3 & \multirow[t]{3}{*}{ ns } \\
\hline & & III-e & 0 & \\
\hline & & III-X & 0 & \\
\hline \multirow[t]{2}{*}{ III D } & \multirow[t]{2}{*}{1} & IIID 1 & 1 & \multirow[t]{2}{*}{ ns } \\
\hline & & IIID 2 & 0 & \\
\hline IVa & 1 & $\begin{array}{l}\text { IVa-p } \\
\text { IVa-g }\end{array}$ & $\begin{array}{l}1 \\
0\end{array}$ & ns \\
\hline $\mathrm{IVb}$ & 0 & $\begin{array}{l}\text { IVb-p } \\
\text { IVb-g }\end{array}$ & $\begin{array}{l}0 \\
0\end{array}$ & ns \\
\hline \multirow[t]{5}{*}{$\mathrm{V}$} & \multirow[t]{5}{*}{1} & V-p & 1 & \multirow[t]{5}{*}{ ns } \\
\hline & & V-g & 0 & \\
\hline & & V-e & 0 & \\
\hline & & $V-x$ & 0 & \\
\hline & & 0 & 1 & \\
\hline $\mathrm{n}$ & 117 & $\mathrm{n}$ & 117 & \\
\hline
\end{tabular}

(the Bethesda category "negative for intraepithelial lesions or malignancy" NILM) are now classified as Pap I. These findings include hormonal patterns, repair changes, microglandular hyperplasia, tubo-endometrioid metaplasia, tubal metaplasia, irradiation changes, alterations resulting from inflammation, or the presence of an intrauterine contraceptive device (8). These normal or unsuspicious cell patterns are classified as Pap I in Munich III. These findings were formerly classified as Pap II. Pap II is now reserved for findings of low protective value.

Pap III still marks unclear findings, but categorizes in the same way as the new Pap IV and V on histological characteristics now. This means that cells of squamous (-p), glandular (-g), or endometrial (-e) origin are clearly made visible with their suffixes. Cells of unknown origin get suffixed with "-x".

The Munich II system was criticized to link moderate with mild dysplasia $(8,9)$. In Munich III, Pap IIID is now subcategorized in IIID 1 [cervical intraepithelial neoplasia grade 1 (CIN 1)] and IIID 2 (CIN 2). Also, compared to The Bethesda System, Munich III differentiates between moderate- and high-grade dysplasia. CIN 2 is possibly remissible, which means that depending on colposcopic findings, surgery can be avoided (10). This fact made the new group IIID 2 necessary.
A limitation of our study is that we only investigated 117 Pap smear samples. The single-center design is another limitation. However, we still demonstrated with our study results the differences of the nomenclatures Munich II and III. The former clusters of Munich II have been extended by distinctly defined subgroups, resulting in a more precise way to differentiate cytological findings. Munich III clearly separates patients at risk from those with no evidence of pathology by the new definition of Pap I and II. In our case, 55 patients (47\% of all Pap smear samples) now categorized as Pap I (normal or unsuspicious) in Munich III will receive the next Pap smear in the regular routine checkup interval. The same patients in Munich II (Pap II) had no statement concerning the unsuspicious presentation of the cervical smear. Due to the restrictive use of Pap II and the more precisely defined Pap III, the new nomenclature Munich III improves the positive predictive value (11).

Ethics Committee Approval: Ethics committee approval was received for this study from the ethics committee of Luebeck University (\#12-234).

Informed Consent: Written informed consent was obtained from patients who participated in this study.

Peer-review: Externally peer-reviewed.

Author Contributions: Concept - C.C., C.B., D.B.; Design - C.C., C.B., D.B.; Supervision - D.B.; Materials - D.B.; Data Collection and/or Processing - D.B.; Analysis and/or Interpretation - C.C., C.B., D.B.; Literature Search - C.C.; Writing - C.C., C.B.; Critical Reviews - C.C.

Acknowledgements: We thank Prof. Husstedt for his collaboration in the laboratory.

Conflict of Interest: No conflict of interest was declared by the authors.

Financial Disclosure: The authors declared that this study has received no financial support.

\section{References}

1. Traut HF, Papanicolaou GN. Cancer of the Uterus: The Vaginal Smear in Its Diagnosis. Cal West Med 1943; 59: 121-2.

2. Papanicolaou GN. Atlas of exfoliative cytology: Cambridge: Published for the Commonwealth Fund by Harvard University Press; 1963.

3. Arbyn M, Anttila A, Jordan J, Ronco G, Schenck U, Segnan N, et al. European Guidelines for Quality Assurance in Cervical Cancer Screening. Second edition--summary document. Ann Oncol 2010; 21: 448-58. [CrossRef]

4. Künzel W. Giessener Gynäkologische Fortbildung 1983. XIII. Fortbildungskurs für Fachärzte der Frauenheilkunde und Geburtshilfe: Springer Berlin Heidelberg; 1983.

5. Griesser H, Marquardt K, Jordan B, Kühn W, Neis K, Neumann HH, et al. Münchner Nomenklatur III: gynäkologische Zytodiagnostik der Zervix. Frauenarzt 2013: 2-7.

6. Solomon D, Davey D, Kurman R, Moriarty A, O'Connor D, Prey M, et al. The 2001 Bethesda System: terminology for reporting results of cervical cytology. JAMA 2002; 287: 2114-9. [CrossRef]

7. Marquardt K, Buttner HH, Broschewitz U, Barten M, Schneider V. Persistent carcinoma in cervical cancer screening: non-participation is the most significant cause. Acta Cytol 2011; 55: 433-7. [CrossRef] 
8. Herbert A, Bergeron C, Wiener H, Schenck U, Klinkhamer P, Bulten $\mathrm{J}$, et al. European guidelines for quality assurance in cervical cancer screening: recommendations for cervical cytology terminology. Cytopathology 2007; 18: 213-9. [CrossRef]

9. Kocjan G, Priollet BC, Desai M, Koutselini H, Mahovlic V, Oliveira $\mathrm{MH}$, et al. BSCC, Bethesda or other? Terminology in cervical cytology European panel discussion. Cytopathology 2005; 16: 113-9. [CrossRef]

10. Kuhn W, Gieseking F, Menton M, Link H, Quass J, Kuppers V, et al. Remarks by the Board of the Study Group for Cervical Pathology and Colposcopy on the "Comments on the Publication of Munich Nomenclature III by the Cytology Coordination Conference" by A. Schneider and P. Hillemanns (Geburtsh Frauenheilk 2014; 74: 242243). Geburtshilfe Frauenheilkd 2014; 74: 634-5. [CrossRef]

11. Hillemanns P, Schneider A. Response to the Letters from W. Kuhn et al. and H. Griesser, K. Marquardt and B. Jordan on "Comments to the Publication of Munich Nomenclature III by the Cytology Coordination Conference" (Geburtsh Frauenheilk 2014; 74: 242243). Geburtshilfe Frauenheilkd 2014; 74: 637-8. [CrossRef] 